\title{
AZ IPARI PARKOK HELYZETE MAGYARORSZÁGON
}

\author{
Györbiró-Szabó András \\ Kistérségi Irodavezető \\ Makó Város Önkormányzata
}

Az Ipari parkok fejlesztése Magyarországon az 1990-es évek elején indult - a fejlett nyugateurópai országok fejlesztési irányait és tapasztalatait figyelembe véve - helyi önkormányzatok és vállalkozások kezdeményezései alapján. Motiváló tényezõ volt a leépült ipari üzemek hasznositása, a munkahelyteremtés, a térségi felzárkózás elösegítése, a területek hasznositása.

A kormányzati szerepvállalás az évtized második felében kezdődik, döntően a megindult fejlesztési folyamatok kibontakozásának segítése céljából. Az ipari parkok fejlesztési program indítását motiválta az is, hogy a privatizációs lehetöségek csökkenésével a tökebevonás formái között fokozatosan nő a zöldmezős beruházások és a reorganizációval ipari parkká szervezhető ipartelepek szerepe. A privatizáció során állami tulajdonba maradt vagyon (korábbi ipartelepek) hasznosításához is meghatározó gazdasági érdekek füződtek.

Az eddig eltelt időszakban 190 ipari park kapta meg az „Ipari Park" címet. (1997-ben 28, 1998-ban 47, 1999-ben 37, 2000-ben 21, 2001-ben 13, 2002-ben 14, 2003-ban 5, 2004-ben 1, 2005-ben 15, 2006-ban 19, 2005-ben 1 cím visszavonásra került, 1 lemondott a címröl.

Az ipari parkokban több mint 3200 cég müködik, melyekben 170 ezren dolgoznak. A parkokban müködő vállalkozások adják a hazai teljesítmény több mint negyedét, exportjának több mint harmadát. A parkok infrastruktúrájuk kiépítésére 1992-töl napjainkig 10,5 Mrd Ft költségvetési forrást biztositottak. 2007 és 2013 között a potenciális pályázati forrás elérheti a 250 Mrd Ft-ot is.

Az Ipari Park fejlesztési program sikeres, elsősorban a helyi kezdeményezésre épülő jellegéből következỏen, hiszen a támogatottság és elismertség kiszámíthatatlanul változott. Az Ipari Parkok fejlesztésén, sikerén dolgozó sok szervezet és szakember olyan gazdasági eredményt ért el, amely jelentősen hozzájárult a befektetési ajánlat bóvítésén keresztül a külföldi és hazai tőke beruházásainak növeléséhez. (Megjegyzendő, hogy az „Ipari Park” cím hazai és nemzetközi tekintetben is elismert minősítést jelent, jelentős marketing értéke van.) 
Az ipar és az ipari szolgáltatások fejlesztésén keresztül az ipari szerkezet átalakításához, - a foglalkoztatảsi gondok enyhítéséhez, a munkanélküliség csökkentéséhez,- a regionális - ezen belül különösen a kistérségi - fejlesztési célok megvalósításához, a területi fejlöđési különbségek kiegyenlítéséhez, a program keretét adó „Ipari Park” cím megszerzése szigorú feltételrendszere révén indukált és részben koordinált egy tudatos fejlesztői tevékenységet települési és térségi szinten egyaránt. A program igazi ereje, értéke abban van, hogy valamennyi projekt helyi kezdeményezéssel indult el, az állami szerepvállalás elsősorban a szak̉mai és a pénzügyi támogatás feltételeinek meghatározásában jelent meg.

$\mathrm{Az}$ Ipari Park program további fejlődésének elősegítése, az egyes szakmai kérdések kellő megalapozása igen komoly feladat a Gazdasági és Közlekedési Minisztérium, a társtárcák és a szakmai szervezetek számára egyaránt.

Magyarországi Ipari Parkok a közel tíz éves program alatt meglehetősen eltérő fejlődési pályán mozogva, és egymáshoz viszonyitva is nagyon eltérő eredményeket értek el. Ebben a folyamatban visszatükrözödnek a gyakran változó gazdaságpolitika sajátos hatásai, a támogatáspolitika - parkokat közvetlenül is érintő - instabilitása, a piaci- és befektetöi konjunktúra ingadozásai. Tovább árnyalta a képet az, hogy az ország európai és a globális gazdasági erőtérbe való beágyazottsága is folyamatosan változik, különösen az $\mathrm{EU}$ csatlakozásunkkal új dimenziókat is kapott ez a folyamat. Másrészt figyelemre méltó a régiós versenytársainkhoz viszonyitott strukturális, illetve versenyképességi problémáink hatása is.

A 185/1996. (XII. 11.) Korm. rendelet (az „Ipari Park” cimröl) felhatalmazása alapján megalkotott és többször módositott 19/1997. (V. 14.) IKIM rendelet alapján (az „Ipari Park" cím elnyeréséröl) a GKM évente hirdetett meg pályázatot az „Ipari Park" cím elnyerésére. 2007-ig már 190 projekt (terület) nyerte el az „Ipari Park” címet. Ténylegesen azonban már egy park visszaadta a címet, és több mint tíz park eddigi müködését eredménytelennek kell tekinteni. Fontos leszögezni azt, hogy az Ipari Parkokat a Gazdasági és Közlekedési Minisztérium mindig vállalkozásnak tekintette.

Ez a nagyszámú, és jelentős arányban gyenge gazdasági- és pénzügyi alapokon álló parki vállalkozás strukturális jellemzője, hogy sokféle Ipari Park típus, profil alakult ki. Magyarországon jelenleg a klasszikus zöldmezős nagybefektetői ipari parkoktól kezdve, a professzionális üzemeltetésủ magán parkokon át a vegyes területhasznosítású barnamezỏs, vagy éppen a logisztikai-, agrár-, vagy egyetemi parkokig igen széles a skála. 
Az Ipari Parkok intézmény-rendszerét és magát a programot (és természetesen a Parkok számának növekedését is) döntően az önkormányzati, illetve a települési és kistérségi gazdaságfejlesztő kezdeményezések alakítják mind a mai napig. Az Ipari Parkok fele önkormányzati töbhségi tulajdonban van, és kétharmadukban van jelen az önkormányzat tulajdonosként. Ez a tulajdoni szerkezet alapvetően meghatározza a fejlesztési forrásokat, a parkok mủködését és a parkok irányítását végző szakemberállomány összetételét.

Az Ipari Parkok dinamikus fejlödésével példamutatóan elötérbe kerültek olyan komplex és fejlett üzleti szolgáltatások is (pl. a logisztika, tanácsadás, innováció stb.), amelyek új perspektívát nyitnak meg a hazai Ipari Parkok kistérségi, illetve nagyobb - regionális léptékü - fejlődése elött. A rendszerben számos biztató példa van. Jó néhány projekt kiemelkedő eredményeket ért el az Ipari Park betelepítésében, valamint a vonzási körzetében lévő vállalkozások integrációjában és a szolgáltatások nyújtásában.

A különbözőségek és egyenlőtlenségek meliett az Ipari Parkok fejlődése új szakaszba érkezett. További fejlödésük egyik fontos feltétele a gazdasági kapcsolatok megteremtése továbbépítése. Kiemelt fontosságúnak tartjuk továbbá az üzleti, vállalkozási és innovációs infrastruktúra egyre magasabb színvonalú fejlesztését, valamint a logisztikai szolgáltatások további intenziv fejlesztését is.

\section{1. táblázat: AZ IPARI PARK PROGRAM EREDMÉNYEI 2004 ÉV VÉGÉN}

naptári évek szerint

\begin{tabular}{|c|c|c|c|c|c|c|c|c|c|}
\hline kithomsik & $19 \mathrm{~m}$ & 1909 & 1099 & 300 & 3001. & sone & 2006. & 2004 & Vilonds $x$ ( 5 2004/3003) \\
\hline Parkockikzama & $2 . x$ & $\because$ & 112 & 135 & $1+4$ & $1 \in(\theta)$ & 165 & 163 & 4 \\
\hline farteck to ristece tha) & $23 \equiv$ & 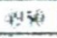 & tato 6 & Titet & $x \sin$ & xavais & wiž & waMx & 905 \\
\hline Intelepictosig (9, ) & $2 t .5$ & 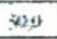 & 52,5 & 329 & $3 \times, 4$ & $3+1$ & 127 & $\sim 7,10$ & +100 \\
\hline IIIllalkox Luank :váana & 320 & 655 & 901 & 109 & $13 d 1$ & 2552 & $2+51$ & 2531 & 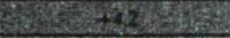 \\
\hline lexsein fecer bis & $z$ & 59 & $8 z$ & 110 & 115 & $13 x$ & 135 & $1+1,5$ & 85 \\
\hline 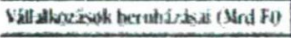 & Kot & 316 & 4 & to: & 1005 & 1264 & 1256 & 1540 & \\
\hline Vill alloredvolk interitude (Nind Fo & 619 & $9 \leqslant 0$ & 1651 & Shó5 & 3.59 & 5456 & 430 & $i$ is & \\
\hline 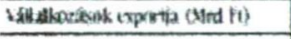 & $51+$ & 6098 & $1: 81$ & 2211 & 2560 & $25 \%$ & 270 & $3+0 \%$ & \\
\hline Eypur ariaga (e) & 83 & 75 & -8 & 83 & is & -5 & 66 & $-91,5$ & 8 \\
\hline
\end{tabular}

Forrás: Okipsz

Az „Ipari Park" címet elnyert 190 projekt többsége folyamatosan fejlödik, 2004. év végén már 151 ipari parkban van több vállalkozás, átlagosan $17 \mathrm{db}$. A parkok többsége rendelkezik betelepedésre alkalmas infrastruktúrával és EU normáinak megfelelő rendezési-, területfelhasználási- és környezetvédelmi szabályozással. 
Az Ipari Parkok a létrehozásukat elősegitő fejlesztési programról szóló döntés (1996), majd a szervezett programindítást (1997) követően gyors fejlödésnek indultak. A fejlődés kezdeti szakasza alapjában véve mennyiségi fejlődést jelentett, kihasználva a kedvező gazdasági konjuktúrát és Magyarország kedvezö befektetési megitélését.

A parkok fejlödése a 2001-2003-ban bekövetkezett visszaesés időszakában csökkent ugyan, de nem tört meg, 2004-ben újabb lendületet vett. A monitorizált, évenként elért eredményeket az alábbi táblázat foglalja össze: Az Ipari Parkok gazdasági teljesítménye - a betelepült vállalkozások jellegénél fogva természetes módon - jobban ki vannak téve a nemzetközi töke (pozitív, vagy éppen negatív) hatásainak. 2002-2003-ban ez néhány multinacionális cég termelésének megszüntetésében is testet öltött, ennek ellenére jelentösen nött a parkokba betelepült cégek száma, amelyek jellegüknél fogva kis- és közepes méretủ vállalkozások. Ez biztató jelenség, különös tekintettel arra, hogy eközben a parkokban foglalkoztatottak létszáma is igen jelentősen nőtt.

Az Ipari Parkok fejlődési folyamatában - kedvezö jelenségként - a KKV-k Ipari Parkba való betelepítése felgyorsult, és ennek a folyamatnak fenntartása, felgyorsítása igen fontos eleme lesz az Ipari Parkok jövőbeni fejlesztési-fejlödési stratégiájának. Ez a nemzetgazdasági szempontból is igen fontos cél elérése úgy lehetségcs, ha a szolgáltatások színvonalát, kínálatát jelentősen bövítjük, ezen belül kiemelten a logisztikai, az informatikai és innovációs szolgáltatások biztosithatják a parkokba betelepült cégek fejlödését, valamint befektetöi vonzerejük növelését.

Minden körülményt figyelembe véve elmondható, hogy az Ipari Parkok nemzetgazdasági szerepe igen jelentọ̄s, bár egyes régiókban betöltött szerepük eltérő arányú. Az lpari Parkok jövőjét is - egyenként és összességében egyaránt - az határozza meg, hogy mennyiben lesznek képesek segíteni a gazdaság szereplöit immár EU tagként az erösödö versenyben, milyen módon lesznek képesek a vállalkozásokat segiteni abban, hogy a globalizált termelésiszolgáltatási rendszerbe való bekapcsolódásuk sikeres legyen.

$\mathrm{Az}$ Ipari Parkok foglalkoztatási jelentősége sem elhanyagolható, hiszen az ủj munkahelyek létrejötte, a foglalkoztatás növelése legtöbbször olyan telephelyeken müködö vállaikozásoknál lehetséges, ahol van fizikai és infrastrukturális lehetőség a bővítés megvalósítására. Az ipari parkokban megvalósult foglalkoztatás-növekedés - érdekes módon - nem követte szorosan a gazdasági teljesitmény növekedését. Például 2003-ban jelentős létszám-növekményt értek el a parkok: 298 újonnan betelepült mikro-, kis- és közepes 
vállalkozás 11.000 fővel növelte a parkokban dolgozók számát, a gazdasági teljesítmény azonban ilyen arányban nem nött.

2007. év végén a 190 Ipari Parkot tartunk nyilván. Régiónként a parkok száma nagy eltérést nem mutat, de az mindenképpen kitünik, hogy Nyugat-Dunántúli régióban a gazdasági súlyához képest jóval kevesebb számú park müködik. A másik, ezzel bizonyos értelemben ellentétes és szembetünő tény az, hogy a Dél-Dunántúl régióban kisszámú, gazdasági teljesítmény tekintetében a régiók között lemaradt Ipari Park müködik. A régiók Ipari Parkjainak száma, gazdasági teljesítményük természetesen nem független az őket körülvevő gazdasági környezettől. Ugyanakkor általános tapasztalat az, hogy az Ipari Parkok a környezetüket meghaladó módon képesek fejlődni.

Jól látható, hogy a parkok területe folyamatosan nőtt, ez különösen azért jelentős, mert 2004-ben mindössze egy Ipari Park nyert címet (Nyugat-Dunántúl régió), az ország keleti, kevésbé fejlett régióiban is folyamatosan fejlódtek az Ipari Parkok. sajnos a Dél-Dunántúl régió továbbra sem fejlöik, sőt egy park lemondott a címröl.

\section{1. ábra: AZ IPARI PARKOK SZÁMA RÉGIÓNKÉNT}

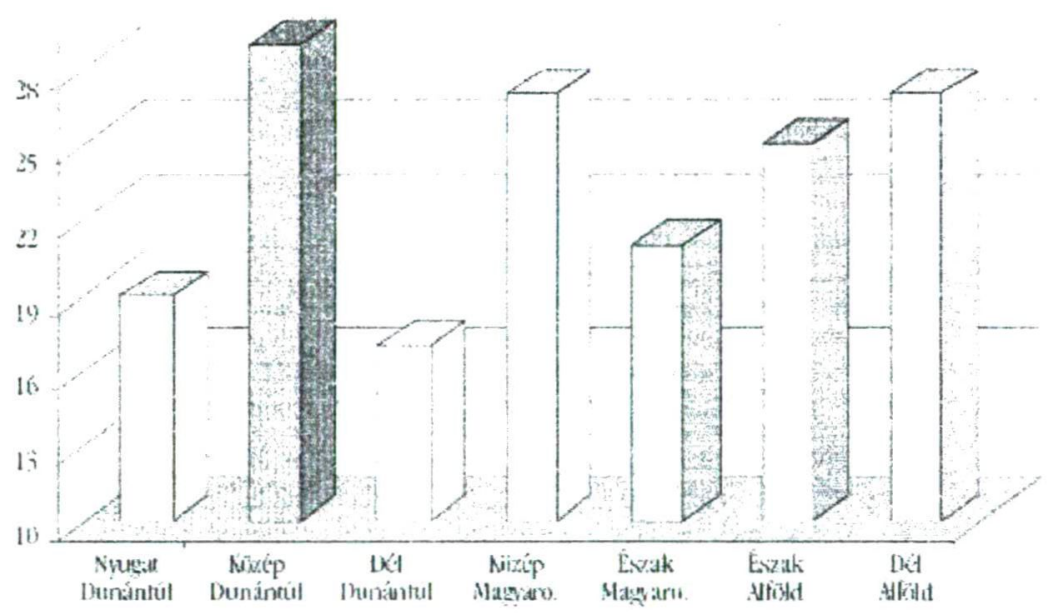

Forrás: Okipsz

2004. év végi adatok alapján az Ipari Parkokban működő vállalkozások száma az elmúlt három évben nőtt, kivéve a Közép-Dunátúli régiót, ahol több (elsősorban külföldi) vállalkozás beszüntette tevékenységét. Az ipari parkokban foglalkoztatottak száma - régiós bontásban is 
- az elmúlt három évben vegyes képet mutat. Észak- Magyarországon és Közép-Dunántúlon folyamatosan nőtt, Észak- és Dél Alföldön csak 2004-ben nőtt, míg Nyugat- és DélDunántúlon és Közép- Magyarország régiókban csökkent. A jelenség hátterében általában a nagyobb cégek tevékenységének „eredménye” keresendő. Ugyanakkor például ÉszakMagyarország régióban a többéves tudatos munka eredménye mellett az M3 autópálya befektetés-ösztönző hatása is érződik.

Az Ipari Parkok fejlődését, „erősségét” a parkokban müködő vállalkozások árbevételének változása is jellemzi. 2002 és 2004 éveit összehasonlító alábbi diagram - a korábban bemutatott folyamatok mellett, illetve ellenére is - a gazdasági eredmények jelentős növekedését jelzik. Különösen fontos kiemelni azt, hogy Észak- Magyarország és a DélAlföld fejlödése önmagához képest is igen jelentös. A Nyugat-Dunántúl növekedésének motorjai a Győr és Szombathely ipari parkjai.

A magyarországi Ipari Parkok összes árbevételén belül megnézzük az egyes régiók teljesítmény-arányai hogyan változtak, akkor igen érdekes kép alakul ki. A jelentősen növekvő teljesítményből Közép-Dunántúl Ipari Parkjainak teljesítmény-aránya a korábbi 45\%-ról 36\%-ra csökkent, míg Nyugat-Dunántúl meg tudta órizni a magas, közel 1/3-os arányt.

\section{2. táblázat: AZ IPARI PARKOKBAN MŨKÖDŐ VÁLLALKOZÁSOK ÁRBEVÉTELÉNEK VÁLTOZÁSA}

(millió Ft)

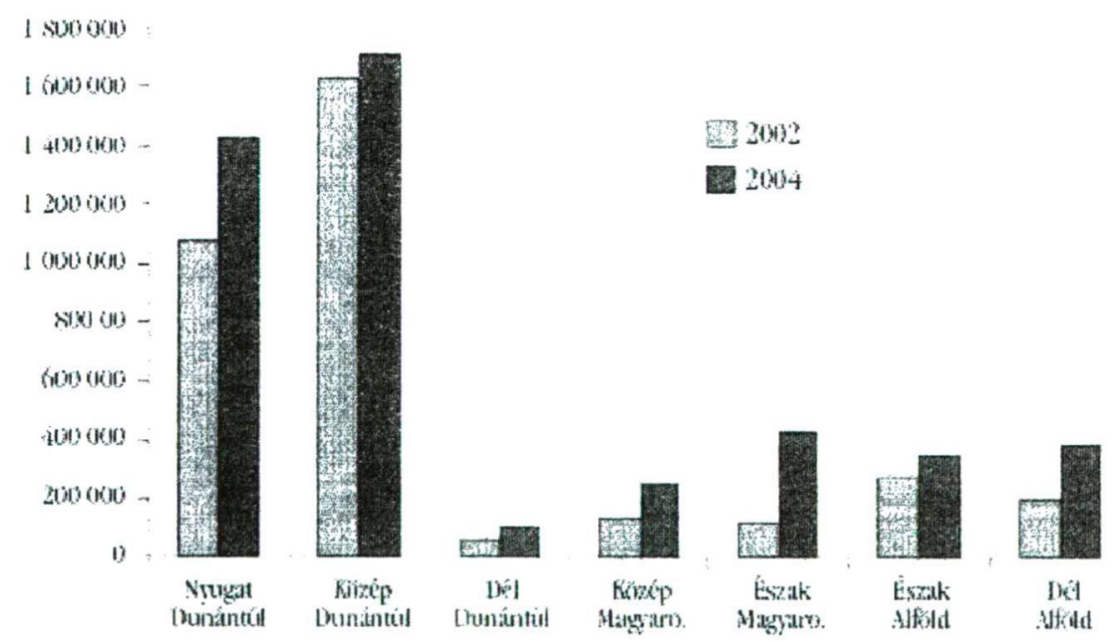

Forrás: Okipsz 
Véleményem szerint a közlekedési fejlesztésekkel is igen szoros összefüggést mutat az ÉszakMagyarország régió intenziv fejlödése, de ugyanez tapasztalható például Dél-Alföldön is, elsősorban a kis- és közepes vállalkozások teljesítményének növekedésének eredményeként. Az önkormányzati tulajdonú Ipari Parkoknak, az általánosan jellemző forráshiányos költségvetési időszakok miatt nincs lehetőségük versenyképesen müködő szervezetet felállítani, azt folyamatosan müködtetve menedzselni és fejleszteni az Ipari Parkot. Nem áll rendelkezésükre a fejlesztéshez szükséges forrás, hiszen minden, a müködtetéssel, fejlesztéssel kapcsolatos költség a sok esetben súlyosan forráshiányos önkormányzati költségvetést terheli. Egyes esctekben a megfelelö szakértelem, a szakêrtők, és kompetenciák is hiányoznak.

Ehhez hasonló körülmények miatt stratégiai fejlesztö partner hiányában az önkormányzati tulaj̣onú Ipari Parkok jó része önkéntelenül versenyhátrányba kerülhet a magánfejlesztésủ Ipari Parkokhoz képest. A sikeres települések Ipari parki fejlesztéséből és működéséből adódó multiplikációs hatások viszont számos új feladat megoldására késztetik az Önkormányzatokat. Az Ipari Parkok keltette hatások nem lokálisak, hanem területi és kistérségi, regionális szintüek is lehetnek, ezért szervesen illeszkednie kell az Ipari Parkok rendszerének a nagyobb integráló struktúrák rendszerébe. A gazdasági fejlödés megnöveli a lakosság letelepülési szándékát, mely a településrendezés aktuális átalakítását vonja maga után. A környezet terhelése, a megnövekedett hulladék, illetve szennyvíz kibocsátás szükség szerint átírja a régiós támogatási prioritásokat is, hiszen kiemelt Európai Uniós cél a hatékony környezetgazdálkodás, környezetvédelem. A gazdasági fellendülés okozta hatások miatt komplex módon kell a fejlesztési elképzeléseket kezelni. Megfelelö kistérségi és regionális összefogással lesznek képesek az önkormányzatok a saját gazdaságfejlesztési érdekeiket érvényesíteni és önmagukat erősítve pozícionálni.

\section{Irodalomjegyzék:}

1. Rakusz Lajos: Ipari Parkok - Üj stratégia, 2004. november 30.

2. Györbiró-Szabó András: Ipari parkok Magyarországon, különös tekintettel a Dél-Alföldön (SZAB pályamunka, 1999)

3. www.okipsz.com

4. www.ipe.hu 